\title{
Wit and wisdom
}

\section{From pioneering xerographer to innovative teacher, Georg Christoph Lichtenberg was a physicist with many skills, but perhaps most remembered will be his acerbic aphorisms.}

\section{John L. Heilbron}

Georg Christoph Lichtenberg (1742-99) has left his name in a few obscure places in the rambling structure of physical science. You can find Lichtenberg's ring on the moon, near the Ocean of Storms; Lichtenberg figures, a precocious anticipation of xerography, in manuals of electrostatics; and Lichtenberg's alloy, of bismuth, lead, and tin, in handbooks of metallurgy. These accomplishments are perhaps insufficient to justify recalling Lichtenberg in this year of physics. What earns him this honour is his unusual pedagogy and his wit, two things that rarely occur together.

Lichtenberg became professor of mathematics and physics at the GeorgAugust University of Göttingen in 1775. Gottingen, the seat of learning of the electorate of Hanover, had close ties with Britain through George III, who put money into its library and sent his sons to study there. During visits to England in the 1770 s, which he undertook at the invitation of English students he had tutored, Lichtenberg caught a bad case of Anglophilia. He became the world expert on the paintings and drawings of William Hogarth; George III made him a privy councillor in 1788 ; and the Royal Society elected him a fellow five years later. Despite a hunched back, the stature of a dwarf, and fragile health, Lichtenberg was a man of great charm. People as diverse as Alessandro Volta and Immanuel Kant admired him.

Lichtenberg gave lectures on experimental physics, which interested even the royal princes. As a teacher he employed a large variety of instruments and machines, and a textbook that he adapted from the Anfangsgründe der Naturlehre composed by his colleague Johann Polykarp Erxleben. Lichtenberg's version was arranged on unusual pedagogical principles. For one thing, it contained a little mathematics, which was not common in physics texts of the time. But the true novelty was that erroneous or superseded statements were retained, together with their corrections, in its successive updated editions.

In this way, Lichtenberg taught physics and modesty together. To err of course is human. In one of the aphorisms in the collection known as The Waste Books, Lichtenberg gave this truth a typical sardonic twist: "To err is human also insofar as animals seldom or never err, or at least only the

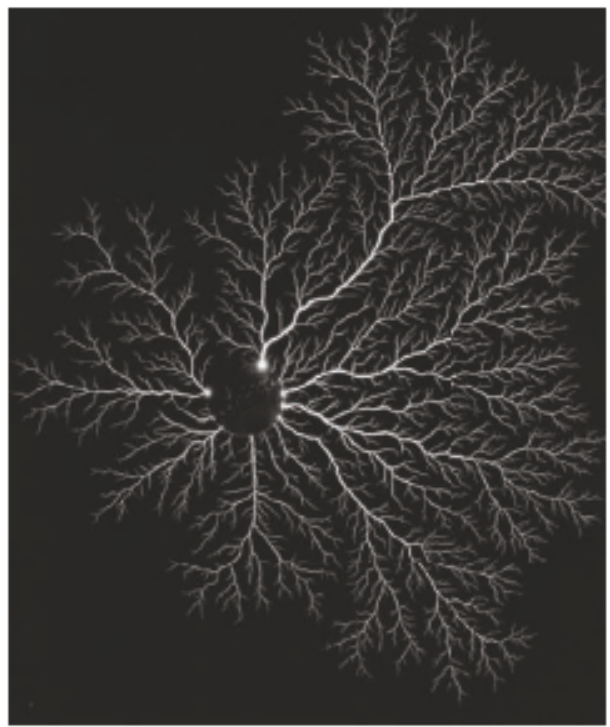

'Lichtenberg's figures' emergedfrom patterns

formed by dust settling on a charged dielectric plate.

cleverest of them do so". Earlier this year the Academy of Sciences of Gottingen issued a very scholarly variorum edition of the Anfangsgrinde as Vorlesungen zur Naturlehre. It will be a fine research instrument for historians. It is unlikely, however, to bring back teaching by disclosure of the teacher's errors.

Lichtenberg regarded the physical hypotheses or models of his time (a century after Newton!) as childish if not infantile. "In physics we have not yet reached puberty. $\mathrm{He}$ foresaw the adult argument that mathematical elegance and simplicity were indicators of truth, and he rejected it "The lofty simplicity of nature all too often rests on the plain simplicity of the one who thinks he sees it."

He also foresaw, and approved, the strategy of building ever-larger instruments. He constructed a big electrophorus based on the design used by its inventor Volta, his great friend and a ladies' man ("ein Reibzeug für die Damen"), just to see what he could find. Having charged the dielectric plate in the usual way, by rubbing it with a docile cat, he saw the dust and shavings he had previously scraped off the plate fly to it and arrange themselves in intriguing patterns. The inventor of the Xerox technique, Chester Carlson, a patent lawyer as well as a physicist, recognized Lichtenberg's patterns as "the first electrostatic recording process".

Benjamin Franklin's lightning rods made no headway in the German states until Lichtenberg intervened in 1780.
Before then, churches had continued their ancient practice of ringing bells to break up thunderclouds, taking a high toll of bell ringers. In 1779, the year before Lichtenberg raised a lightning conductor constructed according to Franklin's instructions, a doctor in Hamburg had tried to construct one. But as he had neglected to ground his conductor, it was as dangerous as a damp rope in a wet belfry.

Lichtenberg not only made clear the functioning of the lightning rod, but also brought to light the "return stroke" - the current that flows through wet ground when a lightning flash annuls the charge induced on the Earth's surface. This current can extend some distance from the point struck. Consequently, as Lichtenberg advised in his droll way, when caught in a field in a thunderstorm, you must walk with your feet together to prevent the return stroke from passing up one leg and down the other.

Lichtenberg's aphorisms, jibes, digs and wisdom are available in modern editions in several languages. Today's English-speaking physicist may find much refreshment in R. J. Hollingdale's excellent translation of The Waste Books. Here are some examples. On modesty: "Physicians should say, not 'I cured him,' but 'he did not die at my hands.' In the same way one should not say in physics, 'I have explained the effect,' but 'I have assigned to it causes whose absurdity no one has as yet been able to demonstrate." On causality: "We have to believe that everything has a cause, as the spider spins its web to catch flies. But it does this before it knows that there are such things as flies." On anthropic hypotheses: " He marvelled at the fact that cats had two holes cut in their fur at exactly the spot where their eyes were." On quantum mechanics: ${ }^{\text {"I }}$ have remarked very clearly that I am often of one opinion when I am lying down and of another when I am standing up." On theorists: "Not only did he not believe in ghosts, he wasn't even afraid of them." On academic blockheads: "Non cogitant, ergo non sunt."

John L. Heilbron is at the Museum for the History of Science, Broad Street, Oxford, UK.

\section{FURTHER READING}

Lichtenberg, J.C. The Waste Books (trans L Hollingdale, R.J.) (New York Review of Books, New York, 1990). Stern, J.P. Lichtenberg a doctrine of scattered occasions, reconstructed fiom his aphorisms and refections (Indiana Univ.Press, Bloomington, 1959). 